in six of the patients, and $60 \mathrm{~mm} \mathrm{Hg}$ was the lowest diastolic pressure recorded. It is also possible that the fall in blood pressure caused by this dose of diazoxide occurred too rapidly, and a further approach might be to lower pressure more gradually by smaller repeated doses.

Despite the theoretical advantages associated with the use of intravenous diazoxide in the treatment of hypertension associated with acute myocardial infarction, the observed electrocardiographic changes in nine of the 20 patients in this study lead us to recommend caution in the use of diazoxide. More detailed studies on haemodynamic changes and detailed enzyme studies might be helpful in confirming or refuting the results suggested by this study.

\section{References}

1 British Medical fournal, 1975, 1, 353.

2 Shell, W E, and Sobel, B E, New England fournal of Medicine, 1974, 291, 481.

${ }^{3}$ Franciosa, J A, et al, Lancet, 1972, 1, 650.

${ }^{4} \mathrm{Kelly}, \mathrm{D}$ T, et al, Circulation, 1973, 47, 729.

${ }^{5}$ Naeim, F, de la Maza, L M, and Robbins, S L, Circulation, 1972, 45, 1231.

6 Nayler, W G, et al, American Heart fournal, 1968, 75, 223.

${ }^{7}$ Rowe, G G, et al, American Heart fournal, 1963, 66, 636.

${ }^{8}$ Scott, J C, and Cowley, A W, American fournal of Cardiology, 1969, 24, 865.

9 Siggers, D C, Salter, C, and Fluck, D C, British Heart fournal, 1971, 33 , 878.

${ }^{10}$ Maroko, P R, et al, Circulation, 1971, 43, 67.

\title{
Trigger factors and HL-A antigens in chronic active hepatitis
}

\author{
JOHAN LINDBERG， ANNIKA LINDHOLM， PER LUNDIN， STEN IWARSON
}

British Medical fournal, 1975, 4, 77-79

\section{Summary}

Forty-six patients with histologically verified chronic active hepatitis (CAH) were divided into three groups according to whether the CAH was virus-induced, druginduced, or cryptogenic. The frequency of the HL-A antigens 1 and 8 was increased in the cryptogenic group while the other groups did not differ significantly from healthy controls. Autoantibodies were often found in high titres in the drug-induced and cryptogenic groups but were infrequent in the virus-induced group.

\section{Introduction}

The aetiology and pathogenesis of chronic active hepatitis (CAH) have been discussed since the disease was first described by Waldenström in $1950 . .^{1}$ Most cases are still considered to be of unknown origin but some are apparently secondary to viral hepatitis or to prolonged use of oxyphenisatin. Autoimmune phenomena such as hypergammaglobulinaemia and tissue antibodies are present to a variable degree, and autoimmune mechanisms are probably involved irrespective of the triggering factor. Recent studies on HL-A antigens in CAH have suggested that genetic factors are associated with this type of abnormal immunoreactivity. ${ }^{2}$

Several cases of $\mathrm{CAH}$ present without demonstrable trigger factors and causes other than hepatitis viruses and oxyphenisatin should be searched for. We attempted to divide 46 patients with $\mathrm{CAH}$ according to possible trigger factors and correlate the distribution of HL-A antigens to such factors.

Östra Sjukhuset (University of Gothenburg), S-416 85 Gothenburg, Sweden

JOHAN LINDBERG, MD, assistant physician, department of infectious diseases

STEN IWARSON, MD, associate professor, department of infectious diseases

PER LUNDIN, MD, professor, department of pathology I

Blood Centre, Sahlgrenska Sjukhuset, Gothenburg, Sweden

ANNIKA LINDHOLM, MD, assistant head physician

\section{Patients and methods}

During 1967-73 65 patients with histologically verified CAH were seen and examined at the clinic for infectious diseases in Gothenburg. Forty-six of these patients, who were seen during their first attack of jaundice in what turned out to be a chronic liver disease, were studied. All patients were examined before any treatment was started. No addict of alcohol or drugs was included and all patients were native Swedes. They were 14-84 years old (mean 52 years) and included 33 women $(72 \%)$.

Serial liver biopsy specimens were obtained by a transthoracic route according to a modified Menghini technique. The histological analyses were made according to principles given by international groups. ${ }^{3}{ }^{4}$ Hepatitis B surface antigen ( HBsAg) was shown in serum by immunodiffusion, immunoelectro-osmophoresis, and radioimmunoassay, as has been described in detail. ${ }^{5}$ Biochemical liver function tests were performed using standard techniques. ${ }^{5}$ The analyses of antinuclear antibodies (ANA), smooth muscle antibodies (SMA), and antimitochondrial antibodies (AMA) were performed by immunofluorescence at the State Bacteriological Laboratory, Stockholm, Sweden.

HL-A antigens were determined by the lymphocytotoxicity microtechnique. ${ }^{6}$ The lymphocyte suspension was prepared according to the technique originally described by Böyum and modified by Thorsby et al. ${ }^{7}$ The frequency of the HL-A antigens in the patients was compared with the frequency in a control group of 690 unrelated healthy Swedes.

\section{Results}

POSSIBLE TRIGGER FACTORS

Virus-induced $C A H$-In 15 patients $(33 \%)$, ranging in age from 27-70 years (mean 53), the initial attack of jaundice was diagnosed as viral hepatitis. Nine of the group were men. Ten of these patients had histological signs of classic viral hepatitis and three also had demonstrable serum HBsAg. In the remaining five patients liver biopsy was not performed during the initial attack of jaundice but the presence of serum HBsAg suggested hepatitis B infection. In three of the eight antigen-positive cases $\mathrm{HBsAg}$ was only transiently demonstrable. These 15 patients were among about 1600 patients with hepatitis admitted to the hospital during the period of study. The interval from the acute attack of viral hepatitis to the first histological signs of CAH ranged from one to five years (mean 1.5). Follow-up liver biopsies because the disease became clinically chronic showed development of chronic aggressive hepatitis histologically in all 15 patients primarily diagnosed as having viral hepatitis.

Drug-induced $C A H-$ Thirteen patients $(28 \%)$, aged 27-75 years (mean 55) and including three men, presented with a histological picture of CAH at their first attack of jaundice and had a history of drug treatment in association with onset of symptoms. The drugs, 
dosage, and duration of treatment are shown in table I. Eight of these patients had taken oxyphenisatin. Five of them had used large doses as laxatives, while three had taken smaller amounts in combination with salicylic acid for pain relief. All patients had been taking drugs for several months or years before the onset of symptoms. Two patients with recurrent urinary tract infections had taken a combination of sulphamethizole and sulphamethoxypyridazine for some months before onset of symptoms. Two patients had taken standard doses of nitrofurantoin for a long period for the same reason and one of them had taken hydrallazine as well. Another patient had used very high doses of phenylbutazone regularly for nearly five years because of joint pains.

Cyrptogenic $C A H$-Eighteen patients (39\%), aged 14-84 years (mean 47), presented with histologically verified $\mathrm{CAH}$ at their first attack of jaundice without serological evidence of viral hepatitis and without a history of drug exposure. All but one of these patients were women.

TABLE I-Drugs, dosage and duration of treatment before first sign of liver dysfunction in 13 patients with possibly drig-induced chronic active hepatitis

\begin{tabular}{|c|c|c|c|c|c|}
\hline $\begin{array}{l}\text { Case } \\
\text { No }\end{array}$ & Sex & $\begin{array}{l}\text { Age at } \\
\text { onset of } \\
\text { illness }\end{array}$ & Drugs & $\begin{array}{l}\text { Dosage } \\
\text { (daily) }\end{array}$ & $\begin{array}{l}\text { Time of } \\
\text { exposure }\end{array}$ \\
\hline $\begin{array}{l}1 \\
2 \\
3 \\
4 \\
5 \\
6 \\
7 \\
8 \\
9\end{array}$ & $\begin{array}{l}\mathrm{F} \\
\mathrm{F} \\
\mathrm{F} \\
\mathrm{M} \\
\mathrm{F} \\
\mathrm{M} \\
\mathrm{F} \\
\mathrm{F} \\
\mathrm{M}\end{array}$ & $\begin{array}{l}27 \\
52 \\
43 \\
60 \\
57 \\
59 \\
75 \\
65 \\
74\end{array}$ & $\begin{array}{c}\text { Oxyphenisatin } \\
\text { ", } \\
\text { " } \\
\text { ", } \\
\text { Sulphamethizole, }\end{array}$ & $\begin{array}{r}20 \mathrm{mg} \\
5 \mathrm{mg} \\
15 \mathrm{mg} \\
5 \mathrm{mg} \\
5 \mathrm{mg} \\
2 \mathrm{mg} \\
2 \mathrm{mg} \\
2 \mathrm{mg} \\
2.4 \mathrm{~g}\end{array}$ & $\begin{array}{l}7 \text { years } \\
10 " \# \\
4 \\
1 \text { " } \\
6 \text { months } \\
3 \text { years } \\
3 \text { "” } \\
5 \text { months } \\
4 \text { mo" }\end{array}$ \\
\hline 10 & $\mathbf{F}$ & 61 & Sulphamethizole, & $\begin{array}{ll}0.0 \mathrm{~g} \\
1.6 \mathrm{~g}\end{array}$ & $"$ \\
\hline $\begin{array}{l}11 \\
12\end{array}$ & $\begin{array}{l}\mathbf{F} \\
\mathbf{F}\end{array}$ & $\begin{array}{l}47 \\
59\end{array}$ & $\begin{array}{l}\text { Phenylbutazone } \\
\text { Hydrallazine, } \\
\text { nitrofurantoin }\end{array}$ & $\begin{array}{r}1.2 \mathrm{~g} \\
75 \mathrm{mg} \\
200 \mathrm{mg}\end{array}$ & $\begin{array}{l}2 \\
5 \text { years } \\
3 \text { " } \\
\text { Several periods }\end{array}$ \\
\hline 13 & $\mathbf{F}$ & 36 & Nitrofurantoin & $200 \mathrm{mg}$ & 1 year \\
\hline
\end{tabular}

\section{DISTRIBUTION OF HL-A ANTIGENS}

The distribution of HL-A antigens was studied in 41 of the patients and was related to the frequency of $\mathrm{HL}-\mathrm{A}$ antigens in a healthy control group of 690 Swedes. The results are shown in table II. HL-A antigens 1 and 8 proved to be of special interest. HL-A 8 was more frequent in patients with drug-induced and cryptogenic $\mathrm{CAH}$ than in those with virus-induced CAH or healthy controls. This difference was statistically significant, however, only for the cryptogenic group compared with the healthy controls $(P<0.01)$. Within the virus-induced group HL-A 8 was not associated with a chronic $\mathrm{HBsAg}$ carrier state in any case. HL-A 1 was also more frequent in patients with drug-induced and cryptogenic $\mathrm{CAH}$ than in those with virus-induced $\mathrm{CAH}$ or healthy controls. Here also the difference was statistically significant only for the cryptogenic group compared with the healthy controls $(P<0.05)$.

TABLE II-Frequency of $H L-A$ antigens ( $\%$ ) in 41 patients with chronic active hepatitis $(C A H)$ divided according to possible trigger factors and 690 healthy unrelated controls

\begin{tabular}{|c|c|c|c|c|}
\hline & $\begin{array}{c}\text { Virus-induced } \\
\text { CAH } \\
(n=13)\end{array}$ & $\begin{array}{c}\text { Drug-induced } \\
\text { CAH } \\
(n=12)\end{array}$ & $\begin{array}{c}\text { Cryptogenic } \\
\text { CAH } \\
(n=16)\end{array}$ & $\begin{array}{c}\text { Healthy } \\
\text { controls } \\
(n=690)\end{array}$ \\
\hline $\begin{array}{ll}\text { HL-A } & 1 \\
\text { HL-A } & 2 \\
\text { HL-A } 3 \\
\text { HL-A } 9 \\
\text { HL-A } 10 \\
\text { HL-A } 11 \\
\text { HL-A } 28 \\
\text { W } 19 \\
\text { HL-A } \\
\text { HL-A } \\
\text { HL-A } \\
\text { HL-A } \\
\text { HL-A } 12 \\
\text { HL-A } 14 \\
\text { HL-A } 17 \\
\text { HL-A } 97 \\
\text { W } 5 \\
\text { W } 10 \\
\text { W } 15 \\
\text { W } 16 \\
\text { W } 18 \\
\text { W } 21 \\
\text { W } 22 \\
\text { TY } \\
\text { W } 20\end{array}$ & $\begin{array}{r}15 \cdot 4 \\
53 \cdot 8 \\
38.5 \\
15.4 \\
15.4 \\
0.0 \\
15.4 \\
30.1 \\
0.0 \\
38.5 \\
30.8 \\
23.1 \\
7.7 \\
7.7 \\
7.7 \\
7.7 \\
7.7 \\
23.1 \\
15.4 \\
0.0 \\
7.7 \\
7.7 \\
0.0 \\
7.7 \\
0.0\end{array}$ & 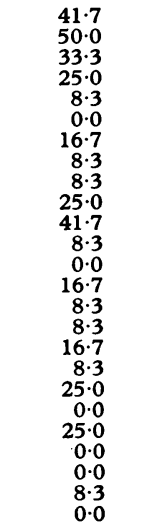 & $\begin{array}{r}56 \cdot 3 \\
62 \cdot 5 \\
12 \cdot 5 \\
25 \cdot 0 \\
0 \cdot 0 \\
6 \cdot 3 \\
12 \cdot 5 \\
18 \cdot 8 \\
12 \cdot 5 \\
18 \cdot 8 \\
62 \cdot 5 \\
25 \cdot 0 \\
0.0 \\
6 \cdot 3 \\
0 \cdot 0 \\
18 \cdot 8 \\
12 \cdot 5 \\
12 \cdot 5 \\
18 \cdot 8 \\
12 \cdot 5 \\
0 \cdot 0 \\
0 \cdot 0 \\
0 \cdot 0 \\
0 \cdot 0 \\
0.0\end{array}$ & $\begin{array}{r}27 \cdot 1 \\
54 \cdot 8 \\
36 \cdot 2 \\
17 \cdot 1 \\
7 \cdot 7 \\
10 \cdot 6 \\
10 \cdot 6 \\
15 \cdot 3 \\
8 \cdot 3 \\
30 \cdot 9 \\
23 \cdot 2 \\
23 \cdot 6 \\
3.3 \\
4 \cdot 5 \\
5 \cdot 2 \\
13.3 \\
12 \cdot 5 \\
21.3 \\
20 \cdot 7 \\
1.9 \\
4 \cdot 1 \\
1.9 \\
3 \cdot 6 \\
0.0 \\
7.8\end{array}$ \\
\hline
\end{tabular}

\section{DISTRIBUTION OF AUTOANTIBODIES}

The distribution of ANA and SMA of IgG-class is shown in the diagram. High titres $(\geqslant 100)$ of ANA and SMA were often found in patients with drug-induced $\mathrm{CAH}(69 \%$ and $34 \%$ respectively). In virus-induced CAH high titres $(\geqslant 100)$ of ANA and SMA were rarely found $(7 \%$ and $0 \%$ respectively).

AMAs (titre $\geqslant 100$ ) were found in only one patient. High titres of ANA, SMA, or AMA of IgM-class were not found.
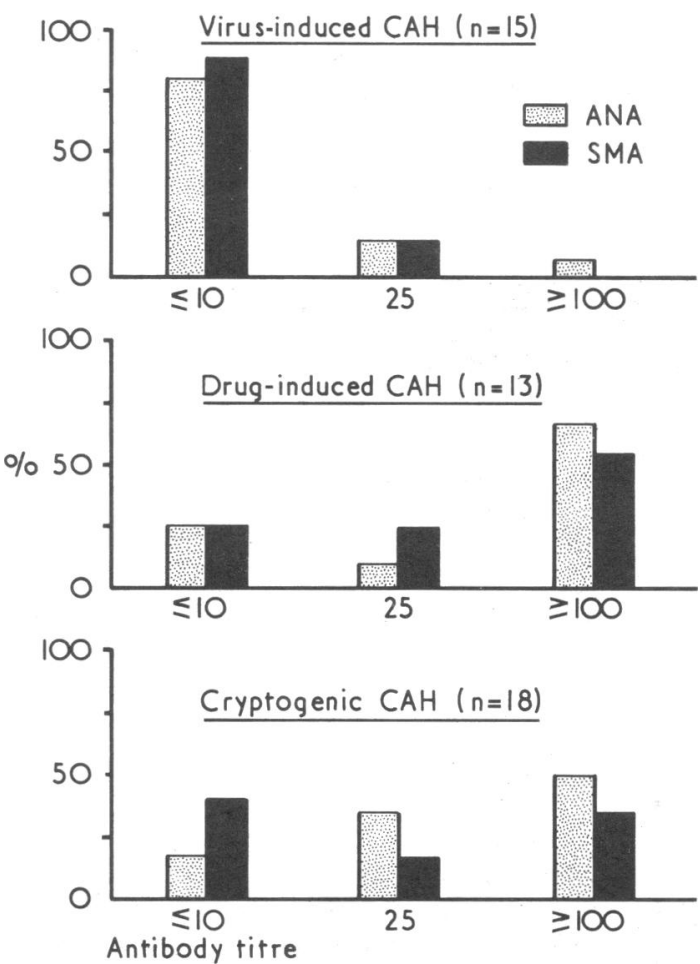

Prevalence (\%) of antinuclear antibodies (ANA) and smooth muscle antibodies (SMA) in 46 patients with chronic active hepatitis (CAH) separated according to possible trigger factors.

\section{BIOCHEMICAL LIVER FUNCTION TESTS}

The three groups of patients showed no significant differences in the peak levels of serum bilirubin and alanine aminotransferase during the initial attack of jaundice. Serum albumin levels were similar in the three groups at that time. Cryptogenic $\mathrm{CAH}$ presented with high levels of serum $\gamma$-globulin (mean $31 \mathrm{~g} / \mathrm{l}$ ) while the virus-induced group had significantly lower levels (mean $18 \mathrm{~g} / \mathrm{l})(\mathrm{P}<0.01)$.

\section{Discussion}

According to a hypothesis by Eddlestone $e$ al $^{8}$ the autoimmune host response in chronic active hepatitis $(\mathrm{CAH})$ is initiated by hepatitis B virus in $\mathrm{HBs} \mathrm{Ag}$-positive cases as well as in several antigen-negative cases. Thus the $\mathrm{HBsAg}$-positive patient cannot eliminate the antigen because of a defect in the humoral antibody defence. By persistent helper $\mathrm{T}$-cell activation an autoimmune reaction is maintained. In the $\mathrm{HBsAg}$-negative patient a suggested defective suppressor $\mathrm{T}$-cell function allows $\mathrm{B}$ cells to synthesize autoantibodies against a liver-specific antigen. In the latter case the helper $\mathrm{T}$-cell effect is only transient but, nevertheless, the autoimmune response persists. It is suggested that drugs act in a similar manner to hepatitis B virus and may thus provoke an autoimmune reaction. This hypothesis ${ }^{8}$ may be applied to our results.

In about a third of our patients with $\mathrm{CAH}$ the initial attack of jaundice was serologically or histologically diagnosed as viral hepatitis, but follow-up studies showed the development of $\mathrm{CAH}$ histologically. About half of these patients were initially $\mathrm{HBsAg}-$ positive and it seems reasonable to assume an aetiological role of 
hepatitis B virus. Other viruses, such as hepatitis A virus, Epstein-Barr virus, or cytomegalovirus, might have been responsible for the disease in HBsAg-negative patients in this (probably) virus-induced group.

Oxyphenisatin, methyldopa, and isoniazid may induce clinical and histopathological changes resembling $\mathrm{CAH} .{ }^{9-11}$ Our findings add a few more drugs to the list of possible trigger agents. Sulphonamides, phenylbutazone, and nitrofurantoin have been associated with acute liver damage, ${ }^{12-14}$ and long-standing exposure to high doses might also be associated with the development of chronic liver disease. Hydrallazine has been associated with clinical and laboratory signs of systemic lupus erythematosus $^{15}$ and might be a trigger factor for $\mathrm{CAH}$ as well.

Almost $40 \%$ of our patients already had morphological signs of $\mathrm{CAH}$ at the onset of clinical illness, and no trigger factor was shown. Cases of $\mathrm{CAH}$ within this group might have been virusor drug-induced, and studies on cellular immunity to $\mathrm{HBsAg}^{16}$ might have shown more cases of probably viral origin.

Some reports have pointed out differences in prevalence of autoantibodies between $\mathrm{HBsAg}$-positive and $\mathrm{HBsAg}$ negative cases of CAH. ${ }^{17}{ }^{18}$ Our results only partly confirm these findings. No HBsAg-positive patient had high titres of autoantibodies, which agrees with previous observations. But HBsAg-negative patients with initial histological signs of viral hepatitis also lacked high titres of autoantibodies. The high prevalence of high-titre autoantibodies in the drug-induced and cryptogenic groups could be at least partly explained by the predominance of women in these groups, as has earlier been claimed by Reed et al. ${ }^{19}$

An increased frequency of HL-A 1 and HL-A 8 was found in the cryptogenic group. Mackay $e t a l^{2}$ reported a high prevalence of HL-A antigens 1 and 8 among 37 patients with CAH who had not been separated according to possible trigger factors. Possibly patients with these HL-A types are more prone to develop CAH without an external precipitating factor. On the other hand, possibly these patients develop $\mathrm{CAH}$ because of impaired suppressor $\mathrm{T}$-cell function, which might be linked to HL-A types 1 and $8 .^{8}$ Thus it is not excluded that some trigger factor could be involved also in cryptogenic CAH. Evidence has been presented that subclinical hepatitis $B$ infection could be such a factor even in patients without demonstrable serum HBsAg. ${ }^{16}$ But other trigger factors-so far undefined-could, of course, be involved in these genetically predisposed patients.

\section{References}

${ }^{1}$ Waldenström, J, Leber, Blutproteine und Nahrungseiweiss Stoffwechselkrauk heiten, Sonderband XV, p 8. Bad Kissingen, Tagung Verlag, 1950.

2 Mackay, I R, and Morris, P J, Lancet, 1972, 2, 793.

${ }^{3}$ DeGroote, J, et al, Lancet, 1968, 2, 626.

${ }^{4}$ Bianchi, L, et al, Lancet, 1971, 1, 333.

${ }^{5}$ Iwarson, S, et al, fournal of Infectiouts Diseases, 1973, 127, 544.

${ }^{6}$ Kissmeyer-Nielsen, F, and Kjerbye, K E, in Histocompatibility Testing, p 381, Copenhagen, Munksgaard, 1967.

7 Thorsby, E, et al, in Histocompatibility Testing, p 655. Copenhagen, Munksgaard, 1970.

${ }^{8}$ Eddleston, A L W F, and Williams, R, Lancet, 1974, 2, 1543.

${ }^{9}$ Reynolds, T B, Peters, R L, and Yamada, S, New England fournal of Medicine, 1972, 285, 813.

${ }^{10}$ Schweitzer, I L, and Peters, R L, Gastroenterology, 1974, 66, 1203.

${ }^{11}$ Maddrey, W C, and Boitnott, J K, Annals of Internal Medicine, 1973, 79, 1.

${ }_{12} \mathrm{~T}$ isdale, W A, New England fournal of Medicine, 1958, 258, 687.

${ }^{13}$ Ecker, J A, American fournal of Gastroenterology, 1965, 43, 23.

${ }^{14}$ Bhagwat, A, and Warren, E, Lancet, 1969, 2, 1369.

${ }^{15}$ Alarcon-Segovia, D, et al, Medicine, 1967, 46, 1.

${ }_{16}$ Lee, W M, et al, British Medical fournal, 1975, 1, 705.

17 Wright, R, Lancet, 1970, 1, 521.

18 Bulkley, B H, et al, Lancet, 1970, 2, 1324.

19 Reed, W O, et al, Lancet, 1970, 2, 690.

\title{
Anthrax in the Gambia: an epidemiological study
}

\author{
B HEYWORTH, M E ROPP, U G VOOS, H I MEINEL, H M DARLOW
}

British Medical fournal, 1975, 4, 79-82

\section{Summary}

Epidemiological data on 448 cases of human cutaneous anthrax from the Gambia showed that this particular strain of anthrax bacillus causes widespread morbidity and some mortality with, at the same time, subclinical infection. Analysis also showed that anthrax is not an occupationally related disease in the Gambia.

\footnotetext{
Medical Research Council Laboratories, Fajara, the Gambia, West Africa

B HEYWORTH, MRCP, DTM\&H, senior lecturer in tropical child health (Present address: Department of Tropical Child Health, Liverpool School of Tropical Medicine, Liverpool L3 5QA

Worldwide Evangelization Crusade Mission, Sibanor, the Gambia M E ROPP, MD, DTM\&H, missionary doctor

U G VOOS, SRN, nursing sister

H I MEINEL SRN, nursing sister

Microbiological Research Establishment, Porton Down, Salisbury H M DARLOW, MRCS, LRCP, safety officer
}

The possibility of human-to-human spread, affecting all age groups and both sexes, by means of a communal toilet article was also shown. The fact that the strain is a good toxin producer but contains a weak antigen may have accounted for the repeated clinical infection and the fact that antibody titres were generally transient. Subclinical infection in animals was also found, particularly in sheep and goats, and also, with an unusually low mortality, in cows. Insect vectors were not exlcuded, but were unlikely. Vultures may spread the disease from village to village. Some possible public health and immunization procedures are discussed, with a view to containing this difficult problem in this part of west Africa.

\section{Introduction}

Anthrax is endemic in certain parts of the world and has been reported most recently from Iran. ${ }^{1}$ Before 1970 anthrax was not reported in the Gambia, though sporadic cases were probably occurring. From 1970 to the end of August 1974 (four dry seasons) nearly 450 cases were seen, diagnosed, and treated in only one area of the Gambia. This paper outlines some of our epidemiological observations. 